\title{
PENGGUNAAN PAKAN KOMPLIT UNTUK SAPI BETINA BIBIT DI KELURAHAN ARO IV KORONG, KOTA SOLOK, SUMATERA BARAT
}

\author{
Tri Astuti ${ }^{1}$, Harissatria ${ }^{2}$, Delsi Afrini ${ }^{3}$ \\ ${ }^{1)}$ Program Studi Peternakan, Fakultas Pertanian, Universitas Mahaputra Muhammad Yamin \\ ${ }^{2,3)}$ Program Studi Agribisnis, Fakultas Pertanian, Universitas Mahaputra Muhammad Yamin \\ email : adektuti@gmail.com
}

\begin{abstract}
Abstrak
Usaha ternak sapi merupakan unit usaha dari kelompok tani Elok Basamo kelurahan Aro Ampek Korong, Kota Solok, Sumatera Barat. Anggota kelompok tani ini merupakan petani yang memelihara sapi sebagai usaha sampingannya. Permasalahan yang ada pada kelompok tani adalah Para anggota kelompok tani kurang memahami manajemen pakan ternak, masih terbatas pengetahuan mereka tentang tata laksana manajemen pemeliharaan, pakan dan sanitasi kesehan ternak, sehingga menjadikan kelompok tani tersebut belum optimal mendapatkan manfaat ternak yang mereka pelihara sebagai faktor penambah pendapatan dan meningkatkan ekonomi keluarga. Kegiatan pengabdian pada masyarakat dengan Program Kemitraan Masyarakat stimulus ini bertujuan untuk memberikan pendampingan dan penyuluhan pada Kelompok tani Elok Basamo tentang manajemen tatalaksana ternak, penyediaan pakan hijauan yang berkualitas. Target khusus dari program ini adalah terjadinya perbaikan manajemen pakan dan konsumsi hijauan yang berkualitas, sehingga mampu untuk berproduksi dan bereproduksi dengan harapan peternak. Metode yang dipakai dalam pencapaian tujuan dengan melakukan percontohan pratek langsung dengan pemberian pakan komplit hijauan dan konsentrat berbasiskan bahan lokal menggunakan formula ransum dengan iso protein dan iso energi. Setelah kegiatan pengabdian ini berakhir luaran yang diharapkan adalah terjadi peningkatan pengetahuan peternak dan akhirnya dapat meningkatnya kesejahteraan petani peternak di kelompok mitra karena terjadinya peningkatan produksi dan reproduksi ternak.
\end{abstract}

Kata Kunci: Manajemen, Pakan, Reproduksi

\begin{abstract}
The cattle business is a unit of the Elok Basamo farmer group, Aro Ampek Korong village, Solok City, West Sumatra. The members are farmers group who raise cows as a side business. The problem with the farmer's group is that members did not understand animal feed management, their knowledge is still limited about the management of maintenance, feed, livestock health sanitation, so the farmer group has not optimally benefited from the livestock and improve the family's economic income. This community service activity with the Stimulus Community Partnership Program aims to provide assistance and counseling to the Elok Basamo farmer group regarding livestock management, providing quality forage feed. The specific target of this program is to improve the management of quality feed and forage consumption so that they are able to produce and reproduce. The method used in achieving the goal was to carry out a direct practical demonstration by providing complete feed forage and concentrate based on local ingredients using a ration formula with iso protein and iso energy. After this service activity ends, the expected outcome is that there will be an increase in breeders' knowledge and ultimately there will be an increase in the welfare of farmer breeders in partner groups due to an increase in livestock production and reproduction.
\end{abstract}

Keyword : Manajement, Feeding, Reproduction 


\section{PENDAHULUAN}

Ternak sapi merupakan salah satu ternak ruminansia yang merupakan pemasok daging nasional sebagai sumber pangan protein hewani. Untuk mendapatkan produksi daging yang optimal baik dari segi kualitas maupun kuantitas tentunya juga dibutuhkan bahan pakan yang berkualitas. Pemeliharaan induk sapi potong dalam jangka panjang bertujuan untuk menghasilkan pedet yang berkualitas dan memiliki harga jual yang tinggi. Tanpa pakan berkualitas ternak unggulpun tidak bisa bereproduksi optimal, karena ada nutrisi pada bahan makanan tertentu merupakan faktor yang sangat berpengaruh mulai dari proses pembentukan fetus dan performans reproduksi, kualitas dan tingkat produksi. Pemberian makanan dengan level rendah pada sapi dara, akan menganggu pertumbuhan sapi dara dan mengalami kesulitan dalam melahirkan (Salisbury dan Vabdemark, 1985).

Pemberian makanan dengan level kualitas nutrisi yang rendah pada induk ternak, akan menganggu pertumbuhan dan mengalami kesulitan melahirkan. Menurut Lubis (1992) pakan adalah segala sesuatu yang dapat dimakan oleh ternak, yang dapat dicerna seluruhnya atau sebagian dan tidak mengganggu kesehatan ternak. Pakan merupakan faktor yang mempunyai pengaruh sangat penting terhadap laju pertumbuhan, apabila kualitasnya baik dan diberikan dalam jumlah cukup, maka pertumbuhan ternak akan lebih baik (Tillman, et al., 1991). Pakan yang diberikan pada ternak diusahakan mengandung zat-zat pakan yang dibutuhkan ternak untuk memenuhi kebutuhan hidup pokok, pertumbuhan, dan reproduksi (Santoso, 2005). Efisiensi reproduksi memiliki peran yang besar dalam meningkatan keuntungan usaha pemeliharaan induk sapi potong.Idealnya seekor induk melahirkan anak satu kali dalam satu tahun atau CI (calving Interval) $=12$ bulan. Keterlambatan bunting pasca melahirkan selama 1 bulan berarti pemborosan biaya pemeliharaan 1 bulan.

Kelompok tani Elok basamo mempunyai unit usaha peternakan sapi yang terdapat di kelurahan Aro Ampek Korong, Kota Solok, Sumatera Barat. Ternak yang sedang dipelihara saat ini terdiri dari 14 ekor ternak sapi betina, yang belum dipelihara dengan manajemen pemeliharaan ternak sapi, hal ini terlihat berdasarkan pengamatan ternak sapi keseharian hanya diberikan rumput lapangan tanpa penambahan konsentrat ataupun rumput unggul lainnya, tapi hanya ditambahkan jerami segar tanpa perlakuan.

Jarak beranak yang menjadi lebih panjang karena peternak juga kurang memahami manajemen reproduksi sehingga dari semua jumlah total sapi betina yang ada hanya 4 ekor betina yang bunting. Hal ini disebabkan salah satu faktor kualitas konsumsi nutrisi yang kurang bagus. Peternak tidak memahami tentang formulasi ransum, dan penggunaan bahan pakan, yang terdapat di alam hasil sampingan pertanian, perkebunan dan holtikultura. Sangat minimnya pengetahuan anggota mitra tentang teknologi pengolahan pakan. Selain itu peternak juga kurang memahami manajemen reproduksi, menentukan waktu yang tepat untuk mengawinkan ternak setelah estrus baik secara alami maupun secara inseminasi buatan. Petani juga belum mampu mengolah limbah peternakan seperti feses dan urin yang mempunyai nilai

Kebiasaan beberapa petani peternak Sapi di Kota Solok masih memelihara ternak secara tradisional, dimana ternak hanya diberi rumput lapangan tanpa penambahan konsentrat untuk memenuhi kebutuhan nutrisi untuk tumbuh dan berkembang. Berdasarkan pengamatan dilapangan permasalahan yang terdapat pada kelompok petani adalah :

1. Sapi betina yang dipelihara belum beranak setelah dipelihara selama 1,5 tahun

2. Kurangnya pengetahuan dan pemahaman peternak mitra dalam mengelola usaha peternakan sapi yang di usahakan.

3. Belum terarahnya program usaha peternakan sapi yang dipelihara oleh peternak sehingga tingkat keuntungan tidak bisa ditingkatkan. 
4. Belum bisanya peternak mengelola pakan yang murah dan komplit berkualitas dari sumber daya lokal yang tersedia di alam.

5. Tidak adanya manajemen reproduksi yang terarah sehingga angka kelahiran tidak bisa terjapai 1 kali dalam satu tahun.

6. Peternak tidak mampu mengolah limbah peternakan seperti feses dan urin sebagai pupuk kompos.

\section{METODE}

Metode kegiatan yang akan dilakukan dan diterapkan dalam pelaksanaan Program Kemitraan Stimulus (PKMS) untuk penyelesaian masalah di kelompok masyarakat peternak sapi ini adalah :

\section{Penyuluhan, Demonstrasi dan Praktek Langsung}

1. Penyuluhan dan praktek langsung kepada peternak sapi tentang masalah perkawinan. Peternak sapi dikumpulkan disuatu lokasi yang telah disepakati sebelumnya dan diberikan penyuluhan tentang reproduksi ternak sapi sampai para peternak tersebut paham tentang masalah reproduksi atau perkawinan ternak yang baik. Termasuk juga masalah sanitasi dan kesehatan ternak yang juga merupakan salah satu faktor penting dalam sebuah usaha peternakan.

2. Selanjutnya adalah memberikan pemahaman melalui penyuluhan tentang pentingnya memberikan pakan berkualitas kepada induk sapi betina

3. Demonstrasi dan Pendapingan membuat ransum yang diformulasikan dengan bahan-bahan pakan yang mengandung nutrien berkualitas berdasarkan ketersediaan di lokasi kandang, harapanya tentu untuk meningkatkan kesuburan ternak sapi betina dan untuk meningkatkan fertilitas.

4. Demonstrasi dan Pendapingan membuat silase pakan komplit

5. Praktek membuat kompos dari feses sapi

\section{HASIL DAN PEMBAHASAN}

Kegiatan PKMS ini diawali dengan koordinasi dengan dinas pertanian peternakan yang merupakan instansi terkait dalam membina peterak yang ada kota Solok yang dilakukan pada tanggal 12 Maret 2020 (Gambar 1), dan didapatlah informasi bahwa 14 ekor sapi betina simental yang dipelihara oleh kelompok tani elok basamo di kelurahan Aro IV korong, ini merupakan sapi hibah bantuan pemda setempat yang telah dipelihara kurang lebih 1,5 tahun, dan sampai kegiatan akan dimulai baru 2 ekor sapi yang bunting. Kegiatan dilanjutkan dengan diskusi secara terfokus dengan anggota kelompok tani peternak untuk mendapatkan masukan dan memetakan permasalahan, yang dilakukan tanggal 18 Maret 2020 (Gambar 2). Hasil diskusi dengan peternak dan pendamping penyuluh lapangan kelompok tani ini didapatkan kondisi bahwa ada 2 ekor ternak sapi tersebut yang sudah dinyatakan bunting oleh petugas Inseminasi Buatan (IB), kemudian setelah 6 bulan kebuntingan tiba-tiba dinyatakan tidak bunting, sehingga membuat kelompok tani peternak ini kecewa. Kemudian disepakatilah rencana kegiatan dengan kelompok tani, dan rencana kegiatan yang telah dibuat sempat tertunda beberapa bulan karena kondisi covid 19 yang memberlakukan pembatasan sosial berskala besar (PSBB) di pemerintahan kota Solok dan kebijakan dikampus yang menghentikan sementara kegiatan pendidikan, penelitian dan pengabdian masyarakat. 


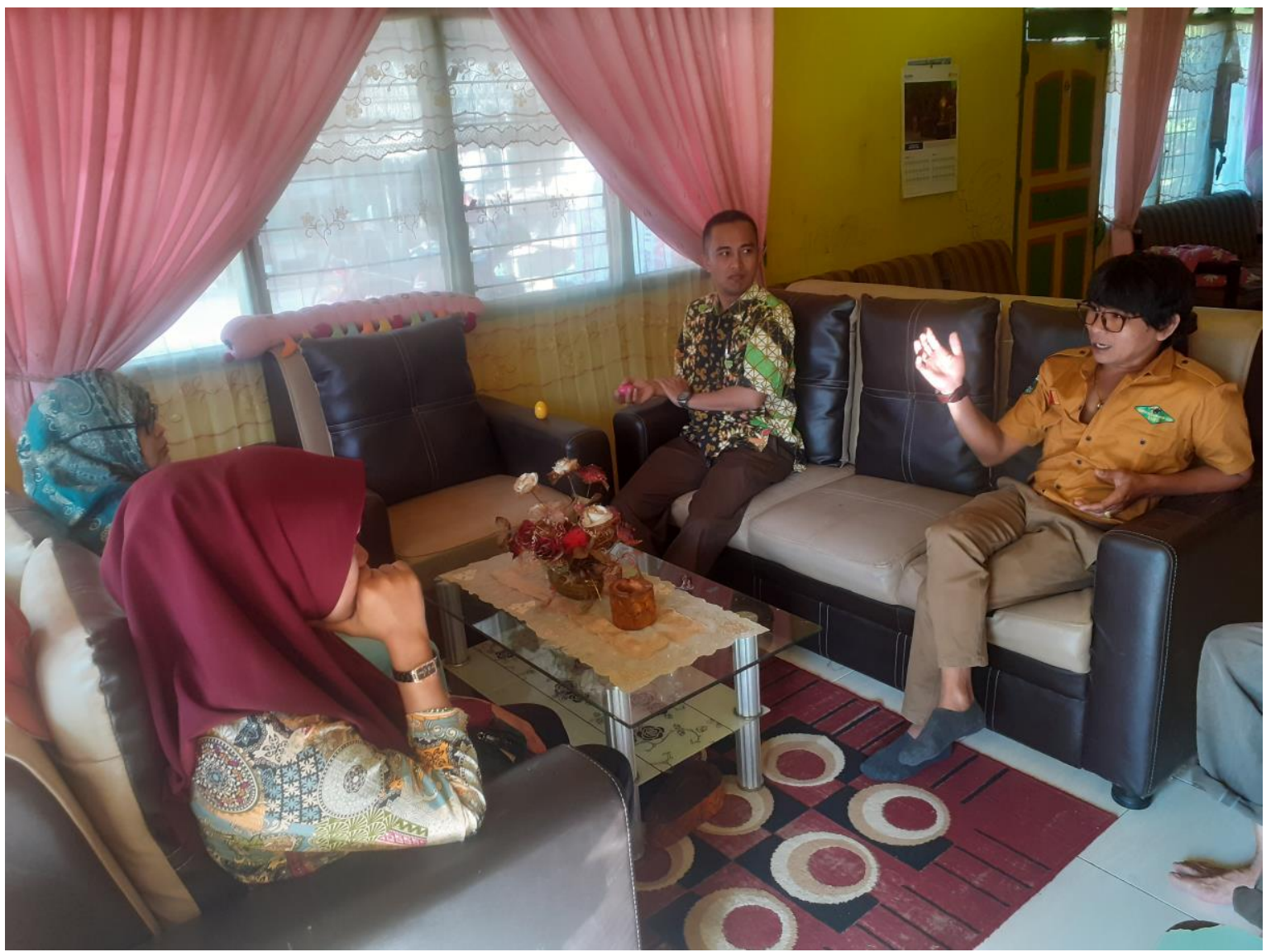

Gambar 1. Diskusi Dengan Pegawai Dinas Pertanian Peternakan Kota Solok

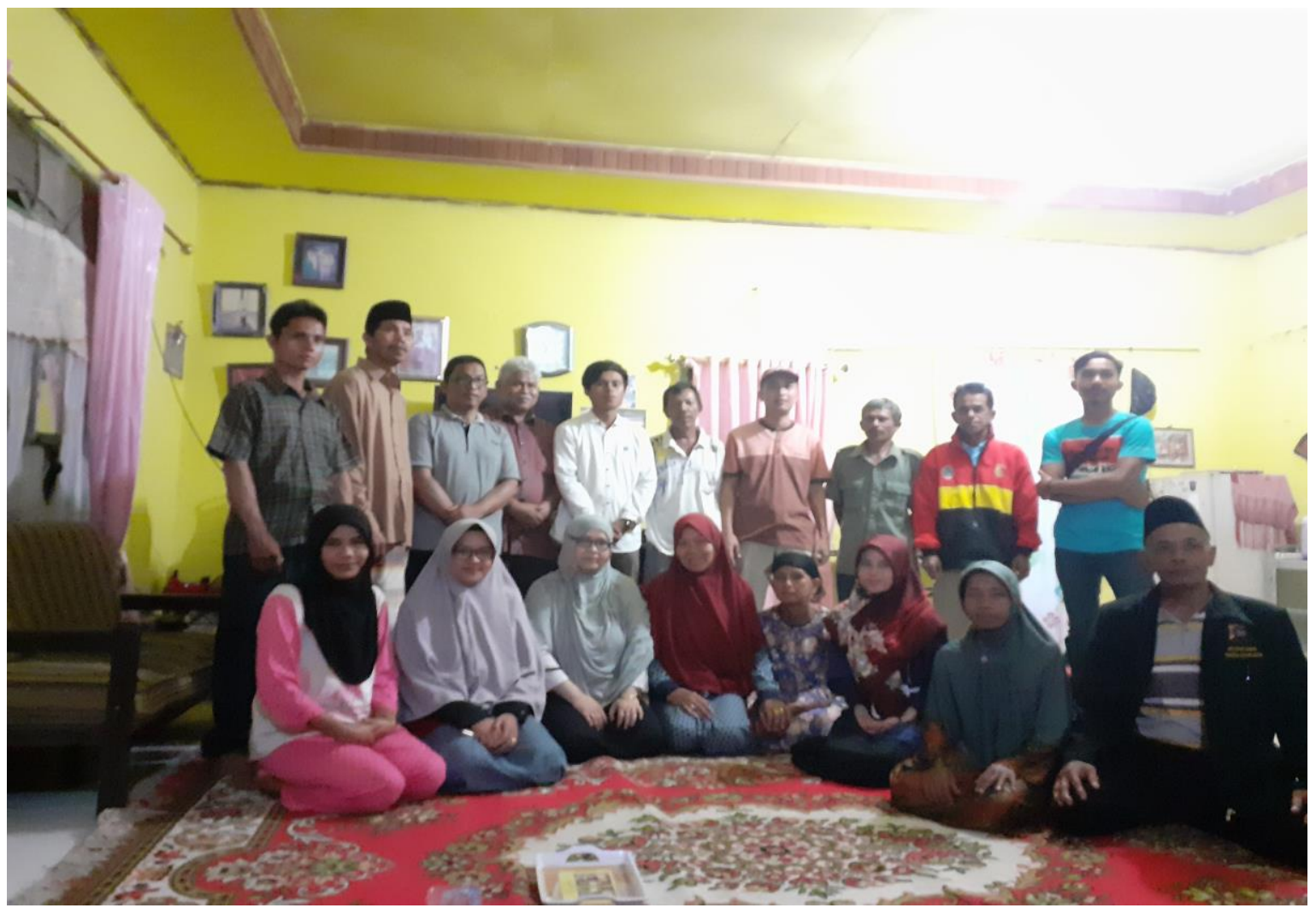

Gambar 2. Diskusi Dengan Anggota Kelompok Tani Ternak Elok Basamo 
Kegiatan yang telah dilaksanakan dalam PKMS ini adalah :

\section{Penyuluhan}

Penyuluhan yang pertama dilakukan adalah tentang bahan pakan, dengan tujuan untuk memberikan informasi pada peternak tentang bahan-bahan pakan, sumber hijauan berkualitas yang ada disekitar lokasi petani seperti tanaman titonia, petai cina, kelor. Pakan yang diberikan kepada sapi potong harus memiliki syarat sebagai pakan yang baik. Pakan yang baik yaitupakan yang mengandung zat makanan yang memadai kualitas dan kuantitasnya, seperti energi, protein, lemak, mineral, dan vitamin, yang semuanya dibutuhkan dalam jumlah yang tepat dan seimbang sehingga bisa menghasilkan produk daging yang berkualitas dan berkuantitas tinggi (Haryanti, 2009). tumbuh sesuai dengan yang diharapkan, jenis pakan yang diberikan pada ternak harus bermutu baik dan dalam jumlah cukup (Tilman, 2008). Kegiatan penyuluhan ini seperti yang terdapat pada Gambar 3. Kemudian menginformasikan pada peternak tentang kebutuhan pakan sapi berdasarkan bobot badan, dan membuatkan formulasi ransum yang terdiri dari konsentrat dengan menggunakan ampas tahu, dedak, bungkil inti sawit, mineral dan rumput tentunya dengan komposisi seperti pada Tabel 1 .
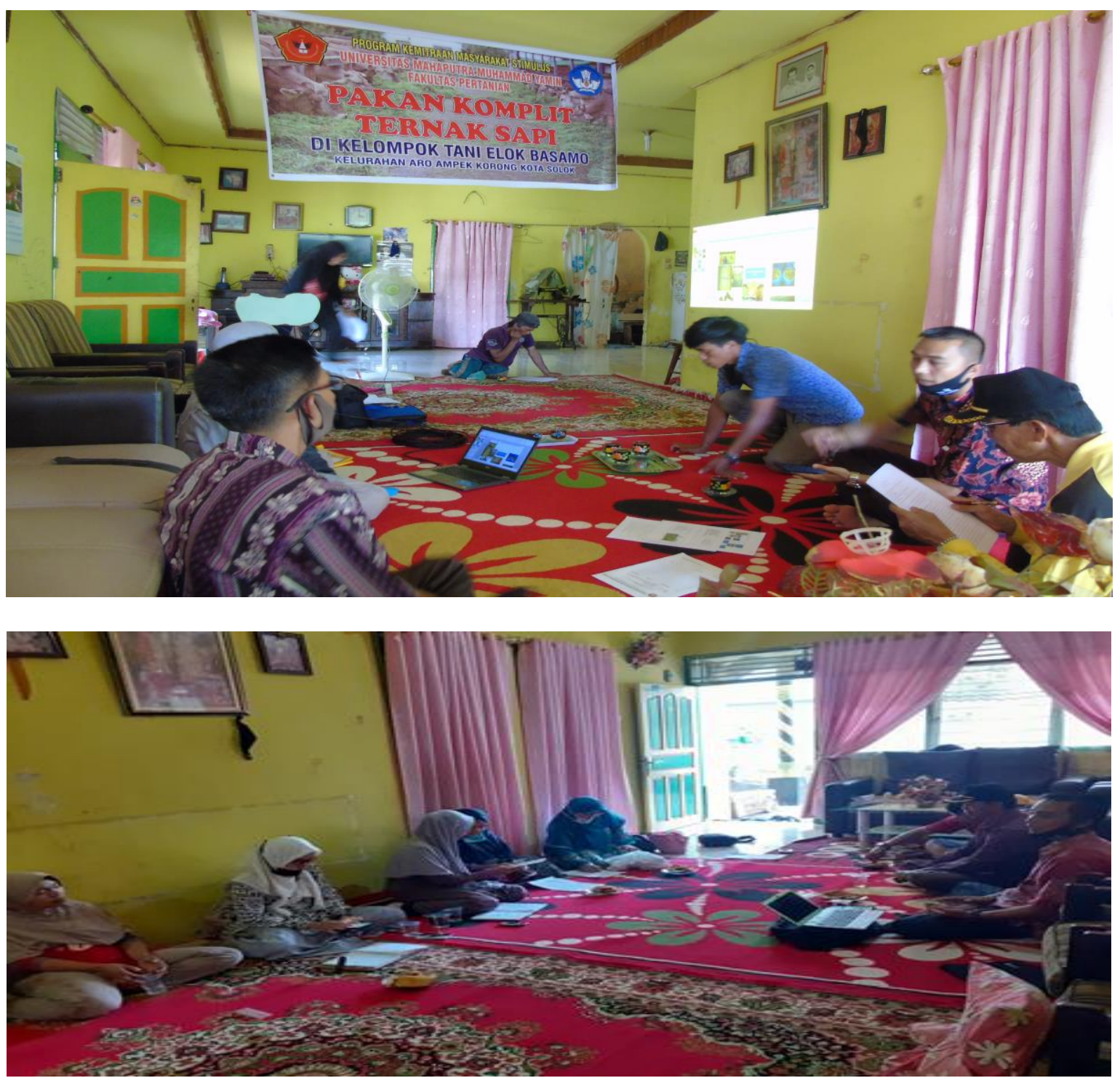

Gambar 3. Penyuluhan Bahan Pakan Dan Pakan Komplit Dan Reproduksi Serta Kesehatan 
ternak

Tabel 1. Susunan Formulasi Konsentrat

\begin{tabular}{|c|c|c|c|c|}
\hline Bahan Pakan & $\% \mathrm{Jum}$ & $\% \mathrm{BK}$ & $\% \mathrm{PK}$ & $\%$ TDN \\
\hline Ampas tahu & 32 & 8,38 & 7,58 & 17,98 \\
\hline Dedak padi & 36 & 32,26 & 4,32 & 24,44 \\
\hline bungkil sawit & 28 & 25,28 & 4,70 & 22,12 \\
\hline Garam & 2 & 1,00 & 0,00 & 0,00 \\
\hline \multirow[t]{2}{*}{ mineral/premiks } & 2 & 2,00 & 0,00 & 0,07 \\
\hline & 100 & 68,92 & 16,61 & 64,61 \\
\hline
\end{tabular}

Pemberian ransum disarankan minimal 10\% bobot badan ternak sapi atau 3\% bobot sapi Berdasarkan Bahan kering. Jika bobot sapi $400 \mathrm{~kg}$ maka minimal harus diberi pakan $40 \mathrm{~kg}$ berat segar, $12 \mathrm{~kg}$ Bahan kering. Kegiatan penyuluhan selanjutnya adalah memberikan materi tentang manajemen reproduksi. Dengan kegiatan ini diharapkan peternak mampu mengetahui tata kelola manajemen reproduksi antara lain pola perkawinan, manajemen pakan, deteksi dan gejala estrus termasuk gangguan reproduksi. Efisiensi reproduksi ternak ditentukan oleh faktorfaktor non genetis, hal ini berarti kegagalan reproduksi banyak dipengaruhi oleh lingkungan dan manajemen. Beberapa faktor yang mempengaruhi performans reproduksi ternak antara lain (1) pola perkawinan yang kurang benar, (2) rendahnya pengetahuan peternak tentang deteksi birahi, (3) rendahnya kualitas atau kurang tepatnya pemanfaatan pejantan dalam kawin alam (4) kurang terampilnya inseminator (5) kurang tepatnya pelaksanaan IB (6), rendahnya pengetahuan peternak tentang manajemen reproduksi, (7) gangguan reproduksi, dan (8) lingkungan termasuk manajemen pakan, (Dwatmadji, 2017).

\section{Demonstrasi Dan Praktek Langsung.}

Setelah melakukan kegiatan penyuluhan, program selanjutnya adalah demontrasi praktek langsung berupa penerapan teknologi formulasi ransum dan pembuatan pakan komplit. Untuk pembuatan pakan dilakukan dua tahap. Tahap pertama adalah pembuatan konsentrat bedasarkan formulasi ransum dengan kandungan protein kasar $16 \%$. Bahan-bahan penyusun ransum terdiri dari ampas tahu, dedak, dan bungkil inti sawit. Kegiatan ini dilakukan pada tanggal 20 Juni 2020 (Gambar 4). Konsentrat yang dibuatkan jika di kalkulasikan bernilai Rp 1000/kg. Konsentra disusun dengan bahan yang terjangkau oleh petani dan mudah didapat disekitar, karena 70-80\% biaya operasional usaha peternakan adalah biaya pakan. Harapannya dengan harga pakan yang murah peternak bisa melanjutkan pemberian pakan setelah program PKMS ini berarkhir.

Demonstrasi berikutnya adalah pembuatan pakan komplit, tepatnya silase pakan komplit yang dilakukan pada tanggal 3 Juli 2020 (Gambar 5). Silase pakan komplit ini merupakan ransum yang disusun dari hijauan dan konsentrat yang lengkap kandungan nutrisinya. Pemberian pakan dapat dilakukan secara langsung tanpa dipisahkan lagi hijauan dan konsentartnya. Menurut Wright dan Lackey, (2008) Pakan komplit campuran berbagai bahan pakan menjadi ransum untuk memenuhi kebutuhan nutrien spesifik sehingga meningkatkan konsumsi nutrien dan efisiensi pakan. Pakan komplit dapat mengandung pakan kasar maupun tidak. 

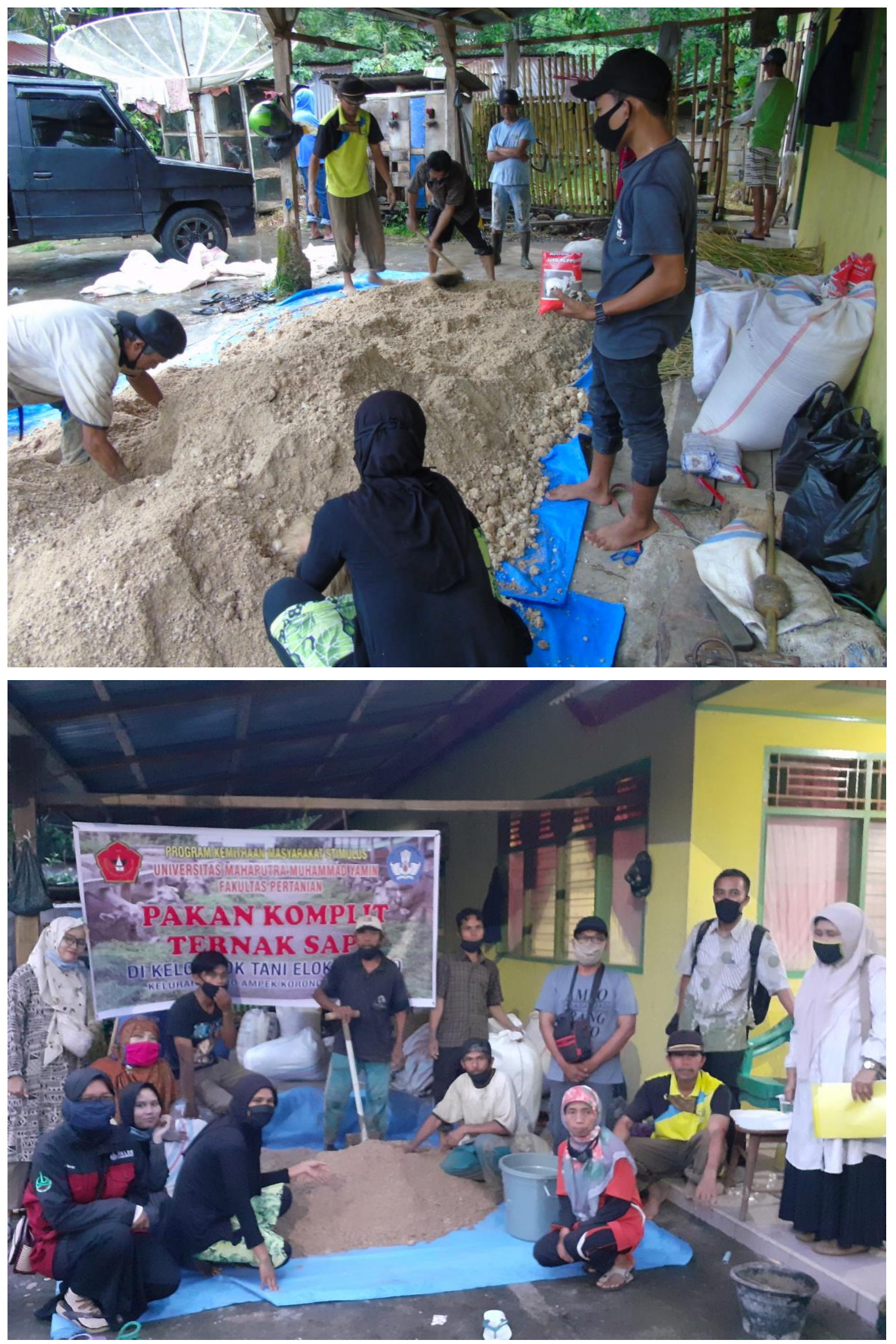

Gambar 4. Praktek pembuatan Pakan 

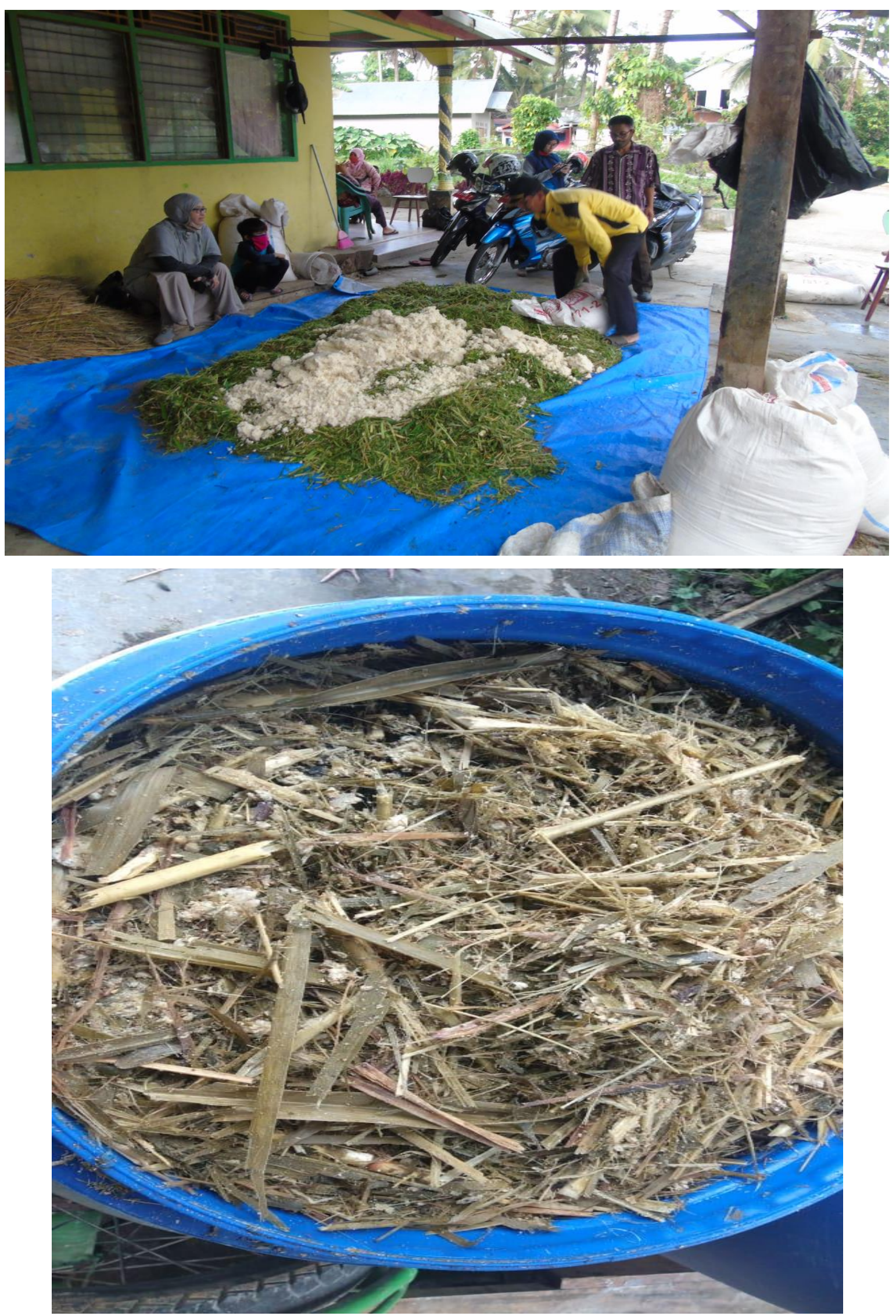

Gambar 5 Praktek pembuatan pakan komplit 
Selain demonstrasi pembuatan pakan, pada kegiatan PKMS ini juga dilakukan pembuatan pupuk organik dari feses sapi yang dicampur dengan jerami dan molases. Selama ini peternak kelompok tani elok basamo ini hanya membiarkan feses sapi mengering dengan sendirinya, dan digunakan saat dibutuhkan. Dengan dilakukannya demonstrasi pembuatan kompos ini diharapkan petani dapat memanfaatkan kompos untuk dijual sebagai penambah pendapatan keluarga. Apalagi saat musim menanam bunga dimasa pandemi covid 19 ini yang tentunya akan banyak yang butuh pupuk. Kegiatan ini dilakukan pada tanggal 11 November 2020 (Gambar 6).

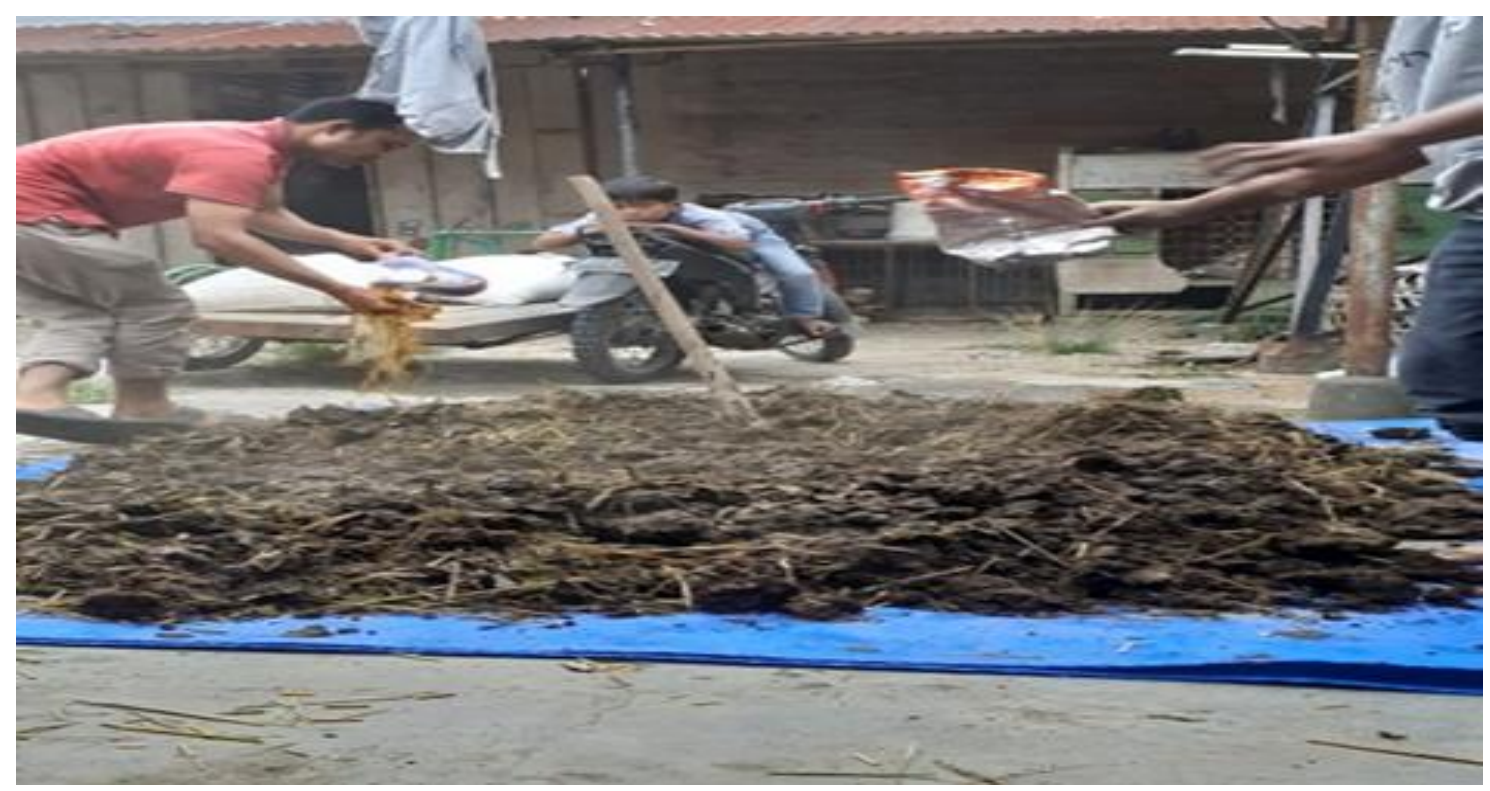

Gambar 6. Pembuatan pupuk Organik dari feses sapi

Diakhir kegiatan ini, seekor ternak sapi anggota kelompok melahirkan yang pertama (Gambar 7). Hal ini merupakan keberhasilan kelompok tani yang dengan kesabarannya memelihara ternak mereka, dan pendampingan dari tim penyuluh dari dinas pertanian kota Solok, dan tentunya ditunjang dengan penyuluhan dan pendampingan dari tim PKMS

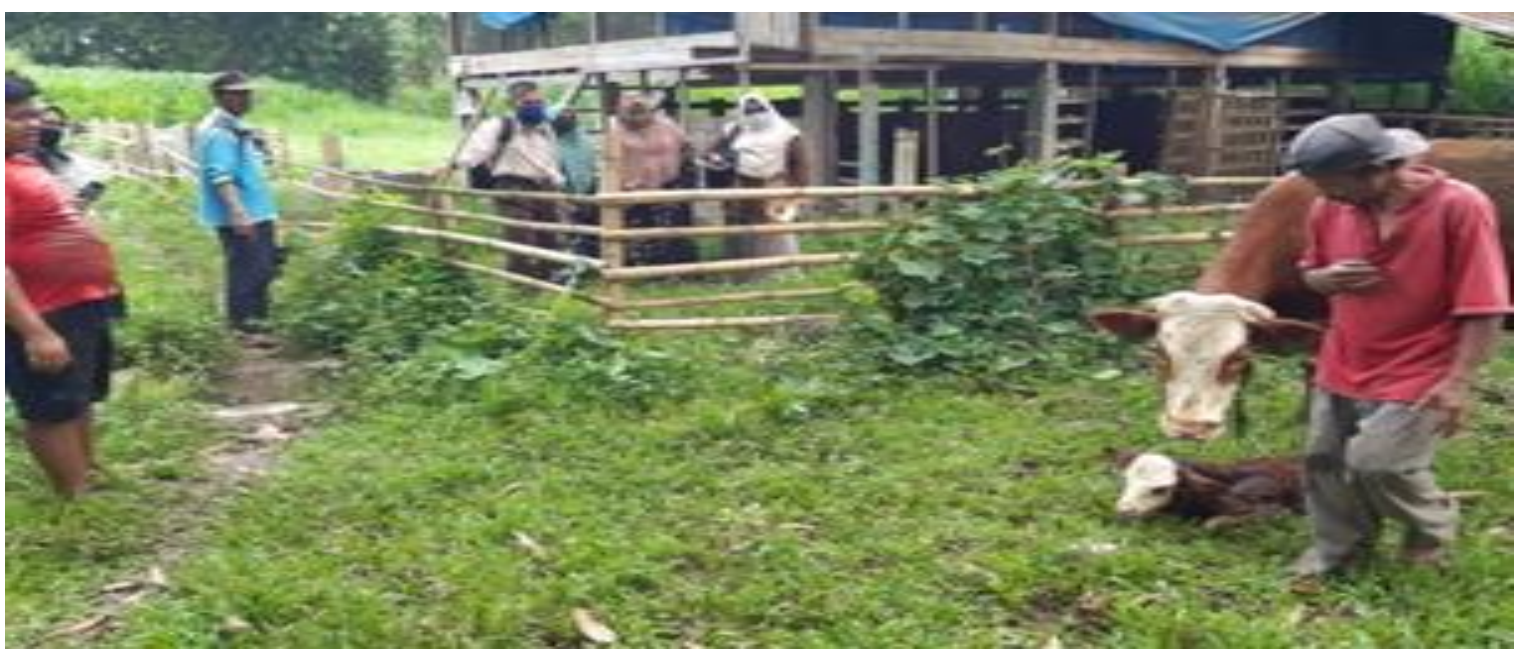

Gambar 7. Sapi Melahirkan Pertama Sejak Dipelihara Petani 


\section{SIMPULAN}

Kegiatan penyuluhan dan pelatihan manajemen pakan dan reproduksi mampu meningkatkan pengetahuan dan wawasan peternak. Ketika peternak mampu mempraktekkan pengetahuan yang diberikan, pemberian pakan yang berkualitas, perkawinan yang tepat, serta kesabaran dalam memelihara sapi, maka akan mewujudkan harapan mereka agar sapinya bisa beranak, yang tentunya akan meningkatkan penambahan pendapatan secara ekonomi

\section{SARAN}

Agar lebih tepat sasaran program pengabdian ini perlu untuk mengadakan peralatan pakan seperti pengaduk/molen, sehingga peternak bisa membuat pakan dalam jumlah yang banyak sehingga bisa disimpan dalam jangka waktu yang lama.

\section{UCAPAN TERIMA KASIH}

Ucapan terima kasih kepada kementerian Ristek dan Teknologi/ BRIN yang telah memberikan pendanaan Kegiatan pengabdian pada masyarakat melalui skim Program Kemitraan Masyarakat Stimulus (PKMS) dengan nomer kontrak No 04.2/LP3M-UMMY/kontrak-pengabmas/2020

\section{DAFTAR PUSTAKA}

Akma G.S., L.W. Pribadi and M. Yassin. 2016. Reproductive Performance of Indigenous Bali Cows in the Different Farming Management and Thermal Environment of Lombok Island Indonesia, Journal of Agriculture and Veterinary Science, 9 (12): 83-89

Dwatmadji, Tatik Suteky, Edi Sutrisno . 2017. Manajemen reproduksi dan pakan untuk meningkatkan performans ternak di desa tugu rejo-kabawetan, kepahiang bengkulu. Jurnal Dharma Raflesia Tahun XVI Nomor 1, Juni 2017.

Haryanti, N.W.2009. Ilmu nutrisi Dan Makanan Ternak Ruminansia. Jakarta: Universitas Indonesia.

Laming, S., 2004, Performans Reproduksi Sapi Perah dan Sahiwal Cross di Kabupaten Enrekang, Skripsi, Fakultas Peternakan Universitas Hasanuddin, Makassar.

Lubis, D.A. 1992. Ilmu Makanan Ternak. PT. Pembangunan. Jakarta

Santoso, U. 2005. Tata Laksana Pemeliharaan Ternak Sapi. Penebar Swadaya. Jakarta

Salisbury, G. W, dan Vandemark. MIL, 1985.Fisiologi dan Inseminasi Buatan Pada Sapi. (diterjemah oleh R. Djanuar). UGM Press. Yogyakarta.

Tillman, A.D., S. Reksohadiprojo, S. Prawirokusumo, dan S. Lebdosoekojo. 1991. Ilmu Makanan Ternak Dasar Cetakan ke-5. Gadjah Mada University Press. Yogyakarta

Wright, T. dan R. Lackey. 2008. Drfinition of Feed Manufacturing and Livestock Nutrition Terms. Ontario Ministry of Agriculture, Food, and Rural Affairs. 